\title{
Effect of Clove Diameter and Plant Growth Regulators on Growth and Yield of Balady Garlic (Allium sativum L.)
}

\author{
Dina S. El-Mesirry and Hebatulla M. Radi ${ }^{1}$
}

\begin{abstract}
The present investigation was laid out during the growing winter seasons of 2015/2016 and 2016/2017 at private farm in Sharnop, Damnhour City, Behera Governorate, to study the effect of clove size and plant growth regulators: 6-Benzylaminopurine (BAP), Naphthalene acetic acid (NAA) on growth and yield of Balady garlic cultivar (Allium sativum L cv).

Experimental design was split plot in a randomized complete blocks design with three replicates. The main plot was clove size, and the sub main plot was growth regulators. The obtained results indicated that vegetative growth characters, bulb yield, its components and bulb characteristics, significantly, affected in case of size of planted bulbs in the both seasons. Obtained results showed that large size (l) gave the highest means values for all studied traits, in both seasons, followed by medium size (m) and small size (s). Moreover, It could be concluded that the vegetative growth characters, bulb yield, its components and bulb characteristics significantly affected with the mix treatment (BAP + NAA) which gave the highest mean values for all studied traits over size of planted bulbs in both seasons, followed by BAP and NAA respectively, in both seasons.
\end{abstract}

Keywords: Balady gaelic, growth regulatprs, clove diameter, vegetative geowth and yield.

\section{INTRODUCTION}

Garlic (Alium sativum L) is an important condiment crop grown in winter season. It is well known that, optimum mother clove size and plant spacing have a great influence on the yield and quality of garlic.

Hence, there have been attempts to improve methods of its cultivation. Apart from the size of planted bulbs growth and yield of bulbous plants can be affected by application of all kinds of growth regulators that enhance plant development processes and improve their quality (Hetman et al. 2007) .

Plant bio regulators (PBRs) have been known to play vital role in bulbing of garlic. It has also been reported that foliar application of PBRs stimulates to form lateral buds and increase the number. of cloves per bulbs. The bio- regulators comprise of both retardants and promoters which when used in appropriate concentration, much influence on the plant architecture in a typical form. It is evident from the literature that the time and the site of application along with concentrations and formulation of different exogenously applied growth regulators are considered as beneficial factor for improving the productivity and quality of horticultural crops, but a little information is available for their effect of garlic. Therefore, an attempt was made to evaluate the effectiveness of different concentrations of PBRs on the growth and yield of garlic which might be help for substantial contribution to the nation.

As the garlic is reproduced exclusively by vegetative means, plant characters such as clove weight or size used for propagation also significant affect the bulb size, yield and quality of garlic (Memane et al 2008). The use of the large sized cloves significantly increases the yield but it also enhances the cost of production by affecting the seed quantity whereas small sized bulbs result into lower yield with lesser cost of production. There is a great need to standardize the size of garlic cloves used for propagation in order to get cost effective results in garlic production (Castellanus et al 2004).

In view of the above mentioned points, the field experiments were conducted to study the effect of plant growth regulator and clove size on yield and quality of garlic.

\section{MATERIALS AND METHODS}

The present investigation was laid out during the growing winter seasons of 2015/2016 and 2016/2017 at private farm in Sharnop, Damnhour City, Behera Governorate, to study the effect of clove size and plant growth regulators: 6-Benzylaminopurine (BAP), Naphthalene acetic acid (NAA)on growth and yield of Balady garlic cultivar (Allium sativum L). The plant material was. Table1 shows some physical and chemical properties of the experiment soil.

Experimental design was split plot in randomized complete blocks design with three replicates. The main plot was clove size, and the sub was growth regulator. Each treatment combination (3clove size $\mathrm{x} 4$ growth regulator). 
Table 1. Physical and chemical analysis of the experimental soil

\begin{tabular}{ll}
\hline Saturated soil extract & \\
\hline $\mathrm{pH}$ & 7.60 \\
$\mathrm{EC}, \mathrm{ds} / \mathrm{m}$ & 1.50 \\
$\mathrm{CaCO}, \%$ & $2.30 \%$ \\
$\mathrm{CEC}, \mathrm{meq} / \mathrm{kg}$ & 30.75 \\
\hline Soluble anions(meq/l) & \\
\hline $\mathrm{Ca}^{++}$ & 5.45 \\
$\mathrm{Mg}^{++}$ & 5.13 \\
$\mathrm{Na}^{+}$ & 10.5 \\
$\mathrm{~K}^{+}$ & 0.23 \\
\hline Soluble anions(meq/l) & \\
\hline $\mathrm{HCO} 3-$ & 8.6 \\
$\mathrm{CL}-$ & 1.65 \\
SO4-- & 11.50 \\
\hline Particle size distribution $\mathbf{( \% )}$ & \\
\hline Sand & 38.7 \\
Silt & 21.8 \\
Clay & 39.3 \\
Soil texture & Clay Loam \\
\hline
\end{tabular}

The 12 treatments comprised of three clove sizes: small seed averaged (1.0-1.5g/clove), medium seed averaged ( $2-2.5 \mathrm{~g} /$ clove) and large seed averaged $(3-4 \mathrm{~g} /$ clove) and four growth regulators: Control, 6-Benzylaminopurine (BAP0.125g/l), Naphthalene acetic acid (NAA 0.125g/l) and mix of the two concentrations. The cloves with the different sizes were soaked at the above growth regulators concentrations over night before planting and water was applied as control while the application of growth regulators was done twice; on the first week of planting, and one month later and water was applied as foliar spray in control plots.Spacing was $25 \mathrm{~cm}$ between bulbs. Each plot consisted of 3 rows $(0.75 \mathrm{~m}$ width, 10 $\mathrm{m}$ long), with $22.5 \mathrm{~m} 2$ plot area.

\section{Preparation of Stock Solutions:}

Different concentrations of auxin (NAA) and Cytokinins (BAP) were prepared by calculating the weight of each hormone by following formula. Calculated weight of each hormone was dissolved in few drops of dilute sodium hydroxide $(\mathrm{NaOH})$ and final volume was made up to the volume required.

Weight required $=$ Molarity $\mathrm{x}$ Molecular weight $\mathrm{x}$ Volume required /1000

\section{The data recorded:}

\section{Vegetative growth characters:}

Ten plants per treatment in each replicate were randomly taken at the end of vegetative growth, 110 days after planting date to determine plant hight $(\mathrm{cm})$, foliage fresh weight (g/plant), foliage dry matter $(\%)$ and number of leaves / plant.

\section{Bulbs yield and its components:}

At harvesting 150 days from planting, all plants for each replicate were harvested. A random sample of 10 bulbs were taken to determinate some bulbs traits i.e., neck diameter $(\mathrm{cm})$, number of cloves/bulbs, bulb diameter $(\mathrm{cm})$ bulb fresh weight $(\mathrm{g} / \mathrm{plant})$ and bulb dry matter . (\%)

\section{Statistical Analysis}

Collected data of the experiments were statically analyzed according to Snedecor and Cochran (1980). Significance between each two means was calculated using, Duncan`s multiple range test, at 5\% level of probability.

\section{RESULTS AND DISCUSSION}

The analysis of variance indicated highly significant differences for the effect of bulbs size and plant growth regulators on growth and yield of garlic.

\section{1- Vegetative growth characters a-Effect of bulb size on vegetative growth:}

Data presented in Table (2) showed that the vegetative characters, significantly, affected by the size in the both seasons. Obtained results showed that Large size (l) gave the highest means values for all studied traits in both seasons followed by medium size $(\mathrm{m})$ and small size (s) except plant height in the both seasons which showed in significant differences between (L) and $(\mathrm{M})$ sizes.

Although plant height is a genetically controlled character in garlic it can be altered by the use of different clove weights and various plant growth (Gasti 1994). Muthulakshmi and Pandiyarajan (2013) reported that Plant hormones are signal molecules produced within the plant, and occur in extremely low concentrations among the plants and generally considered to modulate many physiological events in higher plants. They studied the effect of different concentrations of growth regulators as foliar spray on vegetative growth, physiological and biochemical constituents of Chataranthus roseus (L). The application of growth regulator led to significant increase of vegetative growth characters such as shoot and root length and shoot fresh weights and dry weights. Haydar et al. (2007) proved that planting bulbs of larger diameter in the cultivation of Allium cepa L. had a positive effect on the height of plants, fresh weight of bulbs, and their length. Higher vegetative growth under large clove size might be due to more reserve food material present in the clove in the initial stage of the growth (Deka and Shadeque 1993). 
Table 2. Effect of bulbs size and plant growth regulators on vegetative growth Balady garlic cultivar for both seasons

\begin{tabular}{|c|c|c|c|c|c|c|c|c|c|c|c|c|c|c|c|c|}
\hline \multirow{2}{*}{ Treatment } & \multicolumn{4}{|c|}{ Plant length(cm) } & \multicolumn{4}{|c|}{ Number of leaves / plant } & \multicolumn{4}{|c|}{ Foliage fresh weight(g/plant) } & \multicolumn{4}{|c|}{ Foliage dry matter $(\%)$} \\
\hline & $\mathbf{S}$ & M & $\mathbf{L}$ & Mean & $\mathbf{S}$ & $\mathbf{M}$ & $\mathbf{L}$ & Mean & $\mathbf{S}$ & M & $\mathbf{L}$ & Mean & $\mathbf{S}$ & M & $\mathbf{L}$ & Mean \\
\hline \multicolumn{17}{|c|}{$2015 / 2016$} \\
\hline Control & $64.0 \mathrm{f}$ & $94 \mathrm{bcd}$ & $89.3 \mathrm{cde}$ & $82.4 \mathrm{C}$ & $5.3 \mathrm{~g}$ & $6.3 \mathrm{fg}$ & $8.0 \mathrm{ef}$ & $6.5 \mathrm{C}$ & $65.0 \mathrm{k}$ & $171.0 \mathrm{~g}$ & $170.0 \mathrm{~g}$ & $135.3 \mathrm{D}$ & $20.4 \mathrm{~g}$ & $26.9 \mathrm{e}$ & $30.3 d$ & $25.8 \mathrm{D}$ \\
\hline BAP & 88.0de & $99.6 \mathrm{~b}$ & $96.0 \mathrm{~b}$ & $94.5 \mathrm{~B}$ & 7.3ef & $10.3 \mathrm{~cd}$ & $13.0 \mathrm{ab}$ & $10.2 \mathrm{~B}$ & $126.6 \mathrm{i}$ & $211.3 \mathrm{~d}$ & $254.9 \mathrm{~b}$ & 197.6B & $25.2 \mathrm{f}$ & $29.8 \mathrm{~d}$ & $33.3 b$ & $29.4 \mathrm{~B}$ \\
\hline NAA & $86.6 \mathrm{e}$ & $97.3 b$ & $94.3 b c$ & $92.7 \mathrm{~B}$ & $6.6 \mathrm{fg}$ & $9.0 \mathrm{de}$ & $12.3 \mathrm{ab}$ & $9.3 \mathrm{~B}$ & $105.3 \mathrm{i}$ & $186.0 \mathrm{f}$ & $195.0 \mathrm{e}$ & $162.1 \mathrm{C}$ & $21.1 \mathrm{~g}$ & $29.6 \mathrm{~d}$ & $31.2 \mathrm{c}$ & $27.3 \mathrm{C}$ \\
\hline MIX & $89.6 \mathrm{cde}$ & $95.0 \mathrm{bc}$ & $115 \mathrm{a}$ & $99.8 \mathrm{~A}$ & 8.6de & $11.6 \mathrm{bc}$ & $14.0 \mathrm{a}$ & $11.4 \mathrm{~A}$ & $133.3 \mathrm{~h}$ & $215.6 \mathrm{c}$ & $285.0 \mathrm{a}$ & $211.3 \mathrm{~A}$ & $26.5 \mathrm{e}$ & $29.9 \mathrm{~d}$ & $36.1 \mathrm{a}$ & $30.8 \mathrm{~A}$ \\
\hline Mean & $82.0 \mathrm{~B}$ & $96.5 \mathrm{~A}$ & $98.6 \mathrm{~A}$ & & $7.0 \mathrm{C}$ & $9.3 \mathrm{~B}$ & $11.8 \mathrm{~A}$ & & $107.5 \mathrm{C}$ & 196.0B & $226.2 \mathrm{~A}$ & & $23.3 \mathrm{C}$ & 29.1B & $32.7 \mathrm{~A}$ & \\
\hline \multicolumn{17}{|c|}{$2016 / 2017$} \\
\hline Control & $63.5 \mathrm{~g}$ & 85.0ef & $81.6 \mathrm{f}$ & $76.7 \mathrm{D}$ & $6 \mathrm{~h}$ & $6.6 \mathrm{gh}$ & $8.3 \mathrm{ef}$ & $7.0 \mathrm{D}$ & $64.3 \mathrm{i}$ & $169.6 \mathrm{e}$ & $168.0 \mathrm{e}$ & $134.0 \mathrm{D}$ & $20.0 \mathrm{i}$ & $21.3 \mathrm{~h}$ & $30.0 \mathrm{e}$ & $23.7 \mathrm{D}$ \\
\hline BAP & 88.0de & $98.6 \mathrm{c}$ & $98.6 \mathrm{c}$ & $95.1 \mathrm{~B}$ & $8.3 \mathrm{ef}$ & $11.0 \mathrm{c}$ & $13.0 \mathrm{~b}$ & 10.7B & $124.0 \mathrm{~g}$ & $190.0 \mathrm{c}$ & $253.7 \mathrm{a}$ & 189.2B & $27.1 \mathrm{~g}$ & $32.8 \mathrm{~b}$ & $37.6 b$ & $32.5 \mathrm{~B}$ \\
\hline NAA & 86.6de & $97.0 \mathrm{c}$ & $90.0 \mathrm{~d}$ & $91.2 \mathrm{C}$ & 7.6fg & $9.6 \mathrm{~d}$ & $11.0 \mathrm{c}$ & $9.4 \mathrm{C}$ & $104.3 \mathrm{~h}$ & $181.6 \mathrm{~d}$ & $193.3 \mathrm{c}$ & $159.7 \mathrm{C}$ & $21.3 \mathrm{~h}$ & $28.1 \mathrm{f}$ & $35 c$ & $28.1 \mathrm{C}$ \\
\hline MIX & $95.3 \mathrm{c}$ & $110 \mathrm{~b}$ & $120.0 \mathrm{a}$ & $108.4 \mathrm{~A}$ & $9.0 \mathrm{de}$ & $13.0 \mathrm{~b}$ & $14.6 \mathrm{a}$ & $12.2 \mathrm{~A}$ & $130.0 \mathrm{f}$ & $210.0 \mathrm{~b}$ & $253.7 \mathrm{a}$ & $197.9 \mathrm{~A}$ & $29.6 \mathrm{e}$ & $34.1 \mathrm{c}$ & $39.2 \mathrm{a}$ & $34.3 \mathrm{~A}$ \\
\hline Mean & 83.3B & $97.6 \mathrm{~A}$ & $97.5 \mathrm{~A}$ & & $7.7 \mathrm{C}$ & $10.1 \mathrm{~B}$ & $11.75 \mathrm{~A}$ & & $105.6 \mathrm{C}$ & $187.8 \mathrm{~B}$ & $217.2 \mathrm{~A}$ & & $24.5 \mathrm{C}$ & 29.1B & $35.4 \mathrm{~A}$ & \\
\hline
\end{tabular}

\# Values with the same alphabetical letters, within a comparable group of means, do not significantly differ from one another, using Duncan's multiple range test at 0.05 level of probability.

$\mathrm{S}=$ small bulb, $\mathrm{M}=$ medium bulb and $\mathrm{L}=$ large bulb

Table 3. Effect bubles size and plant growth regulators on yield and its components of Balady garlic cultivars for both seasons

\begin{tabular}{|c|c|c|c|c|c|c|c|c|c|c|c|c|c|c|c|c|c|c|c|c|}
\hline \multirow{2}{*}{ Treatment } & \multicolumn{4}{|c|}{ Number of cloves(Number/Bulbs) } & \multicolumn{4}{|c|}{ Nick diameter(cm) } & \multicolumn{4}{|c|}{ Bulb diameter(cm) } & \multicolumn{4}{|c|}{ Bulbs fresh weight (g/plant) } & \multicolumn{4}{|c|}{ Bulbs dry matter (\%) } \\
\hline & $\mathbf{S}$ & $\mathbf{M}$ & $\mathbf{L}$ & Mean & $\mathbf{S}$ & $\mathbf{M}$ & $\mathbf{L}$ & Mean & $\mathbf{S}$ & $\mathbf{M}$ & $\mathbf{L}$ & Mean & $\mathbf{S}$ & $\mathbf{M}$ & $\mathbf{L}$ & Mean & $\mathbf{S}$ & $\mathbf{M}$ & $\mathbf{L}$ & Mean \\
\hline \multicolumn{21}{|c|}{$2015 / 2016$} \\
\hline Control & $33.8 \mathrm{f}$ & $35.2 \mathrm{ef}$ & $46.2 \mathrm{~b}$ & $38.4 \mathrm{C}$ & $1 \mathrm{~g}$ & $1.4 \mathrm{ef}$ & $1.4 \mathrm{ef}$ & $1.2 \mathrm{D}$ & $3.0 \mathrm{e}$ & $4.2 \mathrm{~d}$ & $4.9 \mathrm{c}$ & $4.0 \mathrm{D}$ & $35.0 \mathrm{~g}$ & $40.0 \mathrm{fg}$ & $90.0 \mathrm{c}$ & $55 \mathrm{D}$ & $30.3 \mathrm{~h}$ & $39.3 \mathrm{e}$ & $44.0 \mathrm{c}$ & $37.8 \mathrm{D}$ \\
\hline BAP & $38.5 \mathrm{~d}$ & $38.3 b$ & $48.4 \mathrm{ab}$ & 41.7B & $1.1 \mathrm{fg}$ & $2.1 \mathrm{bc}$ & $2.3 \mathrm{ab}$ & $1.8 \mathrm{~B}$ & $4.1 \mathrm{~d}$ & $5.8 \mathrm{~b}$ & $5.8 \mathrm{~b}$ & $5.2 \mathrm{~B}$ & $68.3 \mathrm{de}$ & $96.6 \mathrm{bc}$ & 103.6ab & $89.5 \mathrm{~B}$ & $36.3 f$ & $40.0 \mathrm{e}$ & $48.3 b$ & $41.5 \mathrm{~B}$ \\
\hline NAA & $35.2 \mathrm{ef}$ & $37.3 \mathrm{de}$ & $46.1 \mathrm{~b}$ & $39.5 \mathrm{C}$ & $1.03 \mathrm{~g}$ & $1.7 \mathrm{de}$ & $1.9 \mathrm{~cd}$ & $1.5 \mathrm{C}$ & $3.5 \mathrm{e}$ & $4.9 \mathrm{c}$ & $5.4 \mathrm{bc}$ & $4.6 \mathrm{C}$ & $45.0 \mathrm{f}$ & $63.3 \mathrm{e}$ & $96.3 b c$ & $68.2 \mathrm{C}$ & $33.6 \mathrm{~g}$ & $39.6 \mathrm{e}$ & $45.0 \mathrm{c}$ & $39.4 \mathrm{C}$ \\
\hline MIX & $42.1 \mathrm{c}$ & $48.2 \mathrm{ab}$ & $50.2 \mathrm{a}$ & $46.8 \mathrm{~A}$ & $1.4 \mathrm{ef}$ & $2.6 \mathrm{a}$ & $2.5 \mathrm{a}$ & $2.2 \mathrm{~A}$ & $5.1 \mathrm{c}$ & $5.9 \mathrm{~b}$ & $6.8 \mathrm{a}$ & $5.9 \mathrm{~A}$ & $73.3 \mathrm{~d}$ & $100.6 \mathrm{~b}$ & $109.6 \mathrm{a}$ & $94.5 \mathrm{~A}$ & $37.3 \mathrm{f}$ & $42.0 \mathrm{~d}$ & $51.0 \mathrm{a}$ & $43.4 \mathrm{~A}$ \\
\hline Mean & $37.4 \mathrm{C}$ & 39.7B & $47.7 \mathrm{~A}$ & & $1.1 \mathrm{~B}$ & $1.9 \mathrm{~A}$ & $2 \mathrm{~A}$ & & $3.9 \mathrm{C}$ & $5.2 \mathrm{~B}$ & $5.7 \mathrm{~A}$ & & $55.4 \mathrm{C}$ & $75.1 \mathrm{~B}$ & $99.9 \mathrm{~A}$ & & $34.4 \mathrm{C}$ & $40.2 \mathrm{~B}$ & $47.1 \mathrm{~A}$ & \\
\hline \multicolumn{21}{|c|}{$2016 / 2017$} \\
\hline Control & $30.9 \mathrm{~g}$ & $35.9 \mathrm{f}$ & $44.3 \mathrm{~d}$ & $37.1 \mathrm{D}$ & $1.03 \mathrm{f}$ & $1.5 \mathrm{e}$ & $1.5 \mathrm{e}$ & $1.3 \mathrm{D}$ & $3.1 \mathrm{~h}$ & $4.4 \mathrm{f}$ & $5.0 \mathrm{e}$ & $4.2 \mathrm{D}$ & $36.6 \mathrm{~h}$ & $73.3 \mathrm{~g}$ & $88.3 \mathrm{~d}$ & $56.1 \mathrm{D}$ & $24.3 \mathrm{~h}$ & $39.3 \mathrm{f}$ & $39.7 \mathrm{ef}$ & $34.4 \mathrm{C}$ \\
\hline BAP & $36.2 \mathrm{f}$ & $39.3 \mathrm{e}$ & $48.2 \mathrm{~b}$ & $41.2 \mathrm{~B}$ & $1.4 \mathrm{e}$ & $2.2 \mathrm{c}$ & $2.4 \mathrm{~b}$ & $2.1 \mathrm{~B}$ & $4.2 \mathrm{f}$ & $5.8 \mathrm{bc}$ & $6.0 \mathrm{~b}$ & $5.3 \mathrm{~B}$ & $69.6 \mathrm{e}$ & $98.0 \mathrm{c}$ & $104.3 b$ & $90.6 \mathrm{~B}$ & $40.7 \mathrm{ef}$ & $46.7 \mathrm{c}$ & $54.3 \mathrm{a}$ & $47.2 \mathrm{~A}$ \\
\hline NAA & $32.2 \mathrm{~g}$ & $37.3 \mathrm{f}$ & $46.2 \mathrm{c}$ & $38.5 \mathrm{C}$ & $1.2 \mathrm{f}$ & $1.7 \mathrm{~d}$ & $2.1 \mathrm{c}$ & $1.6 \mathrm{C}$ & $3.7 \mathrm{~g}$ & $5.1 \mathrm{de}$ & $5.5 \mathrm{~cd}$ & $4.7 \mathrm{C}$ & $46.6 \mathrm{~g}$ & $64.3 \mathrm{f}$ & $97.6 \mathrm{c}$ & $69.5 \mathrm{C}$ & $36.3 \mathrm{~g}$ & $43.7 \mathrm{~d}$ & $49.7 b$ & $43.2 \mathrm{~B}$ \\
\hline MIX & $39.4 \mathrm{e}$ & $43.9 \mathrm{~d}$ & $51.8 \mathrm{a}$ & $45.1 \mathrm{~A}$ & $1.7 \mathrm{~d}$ & $2.7 \mathrm{a}$ & $2.5 \mathrm{ab}$ & $2.3 \mathrm{~A}$ & $5.2 \mathrm{de}$ & $5.9 \mathrm{bc}$ & $7 \mathrm{a}$ & $6.0 \mathrm{~A}$ & $74.0 \mathrm{e}$ & $100.0 \mathrm{bc}$ & $109.3 \mathrm{a}$ & $94.4 \mathrm{~A}$ & $41.7 \mathrm{e}$ & $48.3 b c$ & $54.7 \mathrm{a}$ & $48.2 \mathrm{~A}$ \\
\hline Mean & $34.7 \mathrm{C}$ & $39.1 \mathrm{~B}$ & $47.6 \mathrm{~A}$ & & $1.3 \mathrm{~B}$ & $2.1 \mathrm{~A}$ & $2.2 \mathrm{~A}$ & & $4.1 \mathrm{C}$ & $5.3 \mathrm{~B}$ & $5.8 \mathrm{~A}$ & & $56.7 \mathrm{C}$ & 76.4B & $99.9 \mathrm{~A}$ & & $35.7 \mathrm{C}$ & $44.5 \mathrm{~B}$ & $49.6 \mathrm{~A}$ & \\
\hline
\end{tabular}

\# Values with the same alphabetical letters, within a comparable group of means, do not significantly differ from one another, using Duncan's multiple range test at 0.05 level of probability.

$\mathrm{S}=$ small bulb, $\mathrm{M}=$ medium bulb and $\mathrm{L}=$ large bulb 
These results are in line with Kotagriwar et al. (1997), who were also of the opinion that larger size cloves resulted in increased plant height due to more reserve food material present in the clove during initial stages of growth in garlic

Leaf is considered as an important functional unit of plant which contributes to yield through its photosynthetic activity. It might be due to comparatively more reserve food material present in the larger cloves than in smaller ones. Similar results have, also, been reported by Memane et al. (2008) and Gautam et al. (2014) for the effect of clove weight on number of leaves in garlic.

\section{b- Effect of growth regulators on vegetative growth character.}

The data in Table (2) showed that the vegetative characters, significantly, affected with the mix treatment (BAP+ NAA) which gave the highest means values for all studied traits in both seasons followed bysingle spray with BAP and NAA, respectively in both seasons, except plant hightand number of leaves, in the first season which there were in significant differences between BAP and NAA treatments. Singh, et al. (2018) recorded that the use of Plant Bio- regulators enhanced the performance of garlic in general compared to untreated control.

\section{c- Effect of the interactions:}

There were significant differences in the interaction between the treatment and the different bulbs size of planted regarding to all studied traits in the both seasons (Table 2). Data showed that mix treatment gave the highest means values for all studied traits in (L) size in both seasons.

\section{2- Garlic bulb yield, and its components and bulb characteristics}

\section{a- Effect of bulbs size on yield and its component:}

The data presented in Table (3) showed that there were significant differences in yield and its components due to using bulb size. In this concern (l) size showed the highest means values for all studied traits, in the both seasons followed by $(\mathrm{m})$ and (s) respectively, except in neck diameter, there were in significant differences between (L) and (M) size, in both seasons.

Hetman, et al. (2013) reported that planting larger bulbs results in better quality of produced plants and in higher total yield expressed in number and weight of bulbs. Similar results were obtained by Ashrafuzzaman et al. (2009) and Halina et al. (2013) who indicated that planting large maternal bulbs increased yield of bulbs in terms of weight and number as well as yield of seeds.

\section{b- Effect of treatments growth regulators on yield and its component:}

All tested treatments increased total yield / Fadden, bulbs fresh weight, number of gloves, bulb diameter, compared with the control during both seasons (Table 3). Data showed that mix treatment gave highest significant mean value for all studied traits in the both seasons followed by BAP and NAA respectively, except in bulbs dry matter in the second season in which there were no significant differences between mix and BAP treatments.

Govind et al. (2015) studied the effect of bioregulators and liquid manuring on vegetative growth, yield and quality of garlic. The experiment comprised with treatments of GA3, NAA, GA3 + Liquid manure and NAA + Liquid manure. They founded that among all treatments, application of (GA3) + Liquid manure improving vegetative growth (plant height, leaf number, basal diameter), bulb yield and fresh and dry weight of bulb, followed by the treatment of NAA. This may due to that GA3 and NAA induced cell division and rapid cell elongation in growing portion causing increase the bulb size as well as number of cloves.

\section{c- Effect of the interactions}

The mix treatment gave the highest means values in (L) size regarding to all studied traits, in the both seasons (Table 3). The same treatment gave the highest mean value in $(\mathrm{m})$ size regarding to the number of cloves, in the first season and nick diameter, in the both seasons. Meanwhile, replicated significant differences between mix and BAP treatments regarding to (l) size on number of cloves, neck diameter and bulbs dry matter, in the second season.

Singh et al. (2014), reported that to enhance the garlic production and productivity as well as quality, them Plant bio regulators (PBRs) have been known to play vital role in bulbing of garlic. It has, also, been reported that, foliar application of PBRs stimulates increase the nnumber. of cloves per bulbs.

\section{REFRENCES}

Ashrafuzzaman, M., M.N. Millat, R. Ismail, S.M. Shahidullah. 2009. Influence of paclobutrazol and bulb sizes on seed yield and yield attributing traits of onion (Allium cepa L.) cv. Taherpuri. Arch. Agron. Soil Sci. 55(6): 609-621.

Castellanus, J.Z., P.V. Tapia, J.L. Ojodeagua, G. Hoyos, G.A. Gonzalez, F.S. Mendez, E.A. Sanchez and A.A. Gardea. 2004. Garlic productivity and profitability as affected by seed clove size، planting density and planting method. HortScience. 39(6): 1272-1277. 
Deka, B.C. and A. Shadeque 1993. Interaction effect of spacing, mulching and clove size on growth and yield of garlic (Allium sativum L). South Indian Horticulture. 41(3): 159-161.

Gasti, V.D. 1994. Response of commercial vegetables to growth retardants. MSc (Agri) thesis، University of Agricultural Sciences, Dharwad، Karnataka. India.

Gautam, N., D. Kumar, R. K. S. Kumar, S. Sharma and B. Dogra. 2014. Growth And Yield Of Garlic (Allium Sativum L) As Influenced By Clove Weight And Plant Growth Regulators International Journal Of Farm Sciences. 4(3): 49-57.

Govind, S., R. Maji, A. Kumawat, A. Pal, S. Kumar and S. Saha. 2015. Improvement Of Growth, Yield And Quality Of Garlic (Allium Sativum L.) Cv. G-282 Through A Novel Approach The Bioscan. 10(1): 23-27.

Halina, L., E. Pogroszewska, W. Durlak, D. Kozak. 2013. The Effect of Bulb Size and Application Method of Asahi S1 Biostimulator On The Growth And Yield Of Allium Moly L. Acta Agrobotanica Vol. 66 (1): 89-94 Doi: 10.5586.

Haydar, A., N. Sharker, M.B. Ahmed, M.M. Han-nan, M.A. Razvy, M. Hossain, A. Hoque, R. Karim. 2007. Genetic variability and interrelationship in onion (Allium cepa L.). Middle-East J. Sci. Res. 2(3-4): 132-134.

Hetman, J., H. Laskowska, and W. Durlak. 2013. The influence selected factors on the yield of Allium moly L. bulbs. Acta Sci. Pol., Hortorum Cultus. 6(2): 23-27. (in Polish)
Kotagariwar, V.V., M.H. Choudhary, M.M. Damke and B.J. Jadho. 1997. Effect of planting methods and clove size on growth, yield and quality of garlic (Allium sativum L) cv Godawari. PKV Research J. 21(2): 182-184.

Memane, P.G., R.S. Tomar, D.K. Kakade, G.U. Kulkarni and R.S. Chovatia. 2008. Effect of clove weight and plant growth regulators on growth and yield of garlic (Allium sativum Linn) cv GG 3 . The Asian Journal of Horticulture. 3(1): 82-86.

Muthulakshmi, S. and V. Pandiyarajan 2013. Effect of IAA on the Growth, Physiological and Biochemical Characteristics in Catharanthus roseus (L). G. Don. S. International Journal of Science and Research (IJSR) ISSN (Online): 2319-7064 Index Copernicus Value

Singh, H. D., S. Maji and S. Kumar. 2014. Influence of Plant Bio-Regulators on Growth and Yield of Garlic (Allium Sativum L.) International Journal of Agricultural Sci. 10 (2): 546-549.

Singh, H. D., S. V. K. Maji and R. K. Yadav. 2018. Influence of Plant Bio-regulators on Growth, Yield and Quality of Garlic (Allium sativum L.). Bulletin of Environment, Pharmacology and Life Science. Bull. Env. Pharmacol. Life Sci. 7 (6):68-71.

Snedecor, G. W. and W. G. Cochran. 1980. Statistical Methods. $7^{\text {th }}$ Ed. Iowa State Univ. Press, Ames, Iowa. USA.

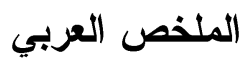

$$
\begin{aligned}
& \text { تأثير قطر الفص والهرمونات النباتية علي نمو ومحصول الثوم البلاي } \\
& \text { دينا صلاح الدين المسيري، هبة الله محمد علي راضي } \\
& \text { كبير في حالة حجم الفص المزروع في الموسـمين علـي } \\
& \text { التو الي. وأوضحت النتائج التي تم الحصول عليها أن الحجم }
\end{aligned}
$$

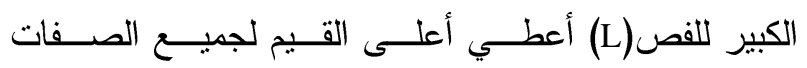

$$
\begin{aligned}
& \text { المدروسة في الموسمين يليها بالحجم المتوسط (M) و الحجم }
\end{aligned}
$$

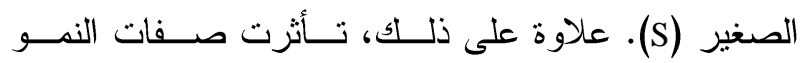

$$
\begin{aligned}
& \text { الخضري، المحصول، مكوناته وخصائصه بشــــل كبيـر }
\end{aligned}
$$

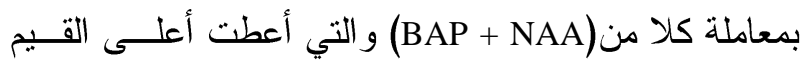

$$
\begin{aligned}
& \text { لجميع الصفات المدروسة على حجم الفص المزروع فــي } \\
& \text { كلا الموسمين يليها ب BAP و NAA على التو الي في كـلا }
\end{aligned}
$$

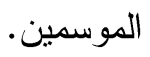

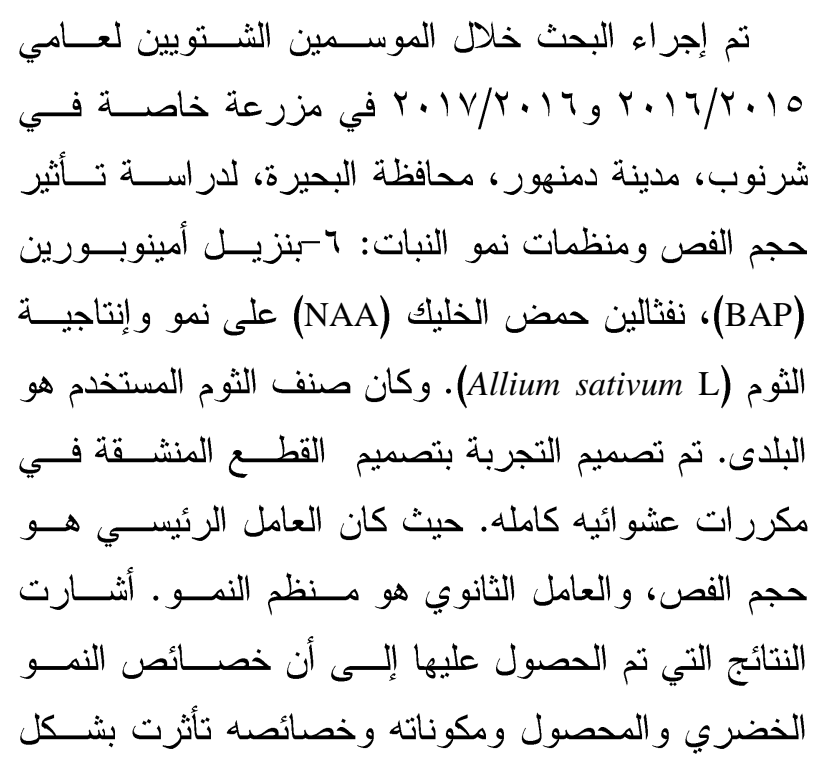
) 